\title{
Municipal Solid Waste Transport Operational Cost of Seberang Ulu Area, Palembang City
}

\author{
Septi Rika Putri $^{1,}$, Khalida Muda $^{1}$, Anis Saggaf ${ }^{2}$, and Dewi Astuti ${ }^{2}$ \\ ${ }^{1}$ Faculty of Civil Engineering, University Teknologi Malaysia, 81310 Johor Bahru, Johor, Malaysia \\ ${ }^{2}$ Engineering Faculty, Civil Engineering Department, Universitas Sriwijaya, Sumatera Selatan, \\ Indonesia
}

\begin{abstract}
Transportation system is an important part of the municipal solid waste management system, and also requires substantial investment and operational costs after the landfill. The further of the service route and the more the number of trucks ritation then the greater the operational costs to be incurred. Transportation system in the research location uses two methods, namely Hauled Container System/HCS (4 units) and Stationary Container System/SCS (19 units), each with $6 \mathrm{~m}^{3}$ capacity. Armroll truck activity analysis found that one time ritation takes an average of 2.72 hours and the average amount of ritation is 3 rit / day. The operational cost required for the armroll truck is $13.433 .68 \mathrm{IDR} / \mathrm{m}^{3} /$ day. The result of dump truck activity analysis obtained the average time in one ritation is 4.77 hours, with the amount of ritation of 2 rit / day. Operating cost for dump truck is $25.400 .1 \mathrm{IDR} / \mathrm{m}^{3} /$ day so HCS method with armroll truck is more effective than SCS method with dump truck, although the number of units is less in the research location, this is due to the investment cost of the carosery which is slightly larger than the dump truck.
\end{abstract}

\section{Introduction}

Providing good municipal solid waste management while ensuring the sustainability of financial management will always be a challenge in developing country cities, where budgetary costs in municipal solid waste management systems have not been a top priority due to limited government funds [1]. Components in municipal solid waste management that require considerable investment and operational costs are on collection and transport systems, in addition to the landfill system. The limitation of these funds has ultimately shown various impacts on the environment, either directly or indirectly. Various research on financing in solid waste management has been done and continues to grow until now. Koushki analyzes the cost of municipal solid waste management in Kuwait and concludes that there are three factors that affect the low cost of the collection and transport system, that are low wage labor and driver, low maintenance costs (due to low wages), and low energy costs [2].

\footnotetext{
*Corresponding author: anissaggaf@unsri.ac.id
} 
Burhamtoro states that the success of transportation system in municipal solid waste management can be measured based on four things: efficiency of time, energy and fuel efficiency, environmental impact, and safety. Burhamtoro analyzed vehicle operating costs with the Pacific Consultants International (PCI) method (1990) that using a regression equation with speed as an independent variable, and conclude that the vehicle fuel component has the highest percentage in municipal solid waste transportation costs $(27.45 \%)$, followed by wages $(18.97 \%)$, and interest rates $(12.09 \%)$ [3]. Olukanni analyzes the selection of the most economical transport system by involving factors that affect the cost of collecting and transporting solid waste, that are vehicle costs, total time spent on garbage collection, and gross travel costs, so it can be concluded that stationary waste collection methods are the most optimal and economical collection method whereby there is a $56 \%$ reduction of conventional methods in the total haulage cost per garbage collection/day [4].

Purpose of this research is to obtain the time needed by the transportation system in bringing solid waste from the collection system to landfill while analyzing the transportation cost of solid waste $/ \mathrm{m}^{3} /$ day in the research location, that are in the area of Seberang Ulu, Palembang city, Indonesia. Selection of the study sites is based that the ulu region is the farthest area of the landfill site, so has the travel time and the most cost when compared the other areas of Palembang city. The Seberang Ulu area consists of four subdistricts; Kertapati, Seberang Ulu I, Seberang Ulu II, and Plaju with an area of $85.86 \mathrm{~km}^{2}$.

\section{Materials and Methods}

Transportation system that brings solid waste from collection systems to landfills with mixed solid waste conditions still uses conventional trucks, armroll and dump trucks with a capacity of $6 \mathrm{~m}^{3}$ and $10 \mathrm{~m}^{3}$. Table 1 shows the average solid waste weight obtained from direct measurements in the collection system (temporary shelter) for seven consecutive days and the number of truck units serving on the collection system. Table 2 shows the capacity and number of ritations of arm roll and dump trucks obtained from direct observation and data from the Environment and Cleanliness Office of Palembang city (2016).

Table 1. The Number of Trucks That Serve Solid Waste To The Landfills (Ritation or Units).

\begin{tabular}{|c|c|c|c|c|c|}
\hline No & $\begin{array}{c}\text { Sub- } \\
\text { districts }\end{array}$ & $\begin{array}{c}\text { Average weight of solid } \\
\text { waste in the collection } \\
\text { system (ton/day) }\end{array}$ & $\begin{array}{c}\text { Percentage } \\
\text { (\%) }\end{array}$ & \multicolumn{2}{|c|}{$\begin{array}{c}\text { Number of trucks } \\
\text { serving (ritation or } \\
\text { units) }\end{array}$} \\
\cline { 5 - 7 } & Plaju & 46.48 & 24.66 & 2 & 4 \\
\hline 1 & 22.4 & 11.90 & 1 & 3 \\
\hline 2 & Kertapati & 34.6 & 18.38 & 1 & 3 \\
\hline 3 & $\begin{array}{c}\text { Seberang } \\
\text { Ulu I }\end{array}$ & 84.9 & 45.05 & 3 & 9 \\
\hline 4 & $\begin{array}{c}\text { Seberang } \\
\text { Ulu II }\end{array}$ & 188.46 & 100 & 7 & 19 \\
\hline
\end{tabular}

There are four sub-districts located in Seberang Ulu area and become the location of the study, the four sub-districts are also densely populated areas and have more low-income 
residents than the Seberang Ilir region. Sub-district Seberang Ulu II has the highest amount of solid waste at the location of the collection system (temporary shelter) so that more trucks that needed to bring the solid waste to the landfill. The number of dump truck trips is $2 \mathrm{rit} /$ day with a capacity of $6 \mathrm{~m}^{3}$ of 18 units, and $10 \mathrm{~m}^{3}$ of 1 unit. While the number of arm roll trips is 3 rit/day with a capacity of $6 \mathrm{~m}^{3}$ and the number of trucks is 4 units.

The pattern of municipal solid waste transport in Indonesia has been regulated in Indonesian National Standard (SNI) Number 19-2454-2002 which examines the Operational Procedures of Municipal Solid Waste Management, which consists of Hauled Container system (HCS) and Stationary Container System (SCS). Armroll truck uses the HCS pattern where the truck with the container leaves the pool to temporary shelter 1 to exchange the empty container with the full container and directly to the landfill, then from the empty trucked truck to the temporary shelter 2 to re-exchange the container with those already containing the garbage and bringing it to landfill, and so on (Figure 3).

While the dump truck uses manual SCS pattern, the truck that goes out of Pool to temporary shelter 1 and the garbage at container at temporary shelter 1 is loaded into the truck manually by human power, then the truck goes to the next temporary shelter and fill truck with trash, and so on until the truck's capacity is full then truck to landfil, empty truck from the landfill will begin a new ritation in the same way (Figure 4).

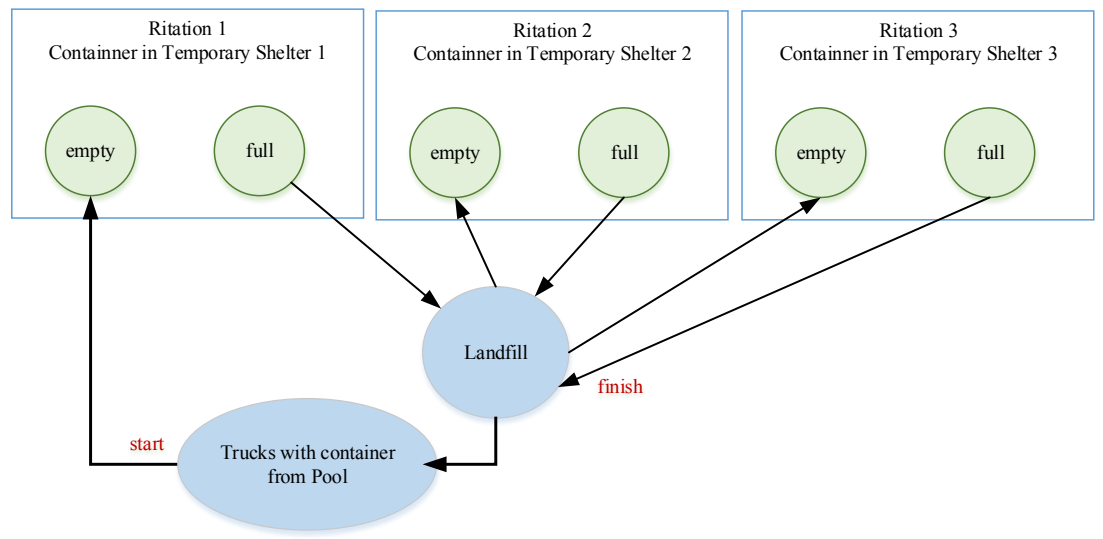

Fig. 1. Armroll Transport system with HCS pattern

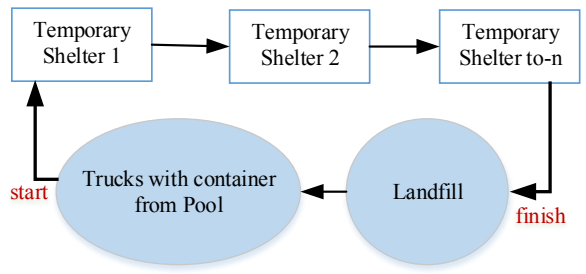

Fig. 2. Dump Trucks Transport system with SCS pattern

There is a difference in the calculation of the number of trips (ritations) on the HCS and SCS patterns due to the time difference required to fill the truck container with the trash in the temporary shelter. The mathematical equations on the transport pattern with the HCS system are: 


$$
\begin{gathered}
\mathrm{P}_{\mathrm{HCS}}=\mathrm{pc}+\mathrm{uc}+\mathrm{dbc} \\
\mathrm{T}_{\mathrm{HCS}}=\mathrm{P}_{\mathrm{HCS}}+\mathrm{h}+\mathrm{s} \\
\mathrm{Nd}=\left[\mathrm{H}(1-\mathrm{W})-\left(t_{1}+t_{2}\right)\right] / \mathrm{T}_{\mathrm{HCS}}
\end{gathered}
$$

where:

$\mathrm{pc} \quad=$ time to take full container (hours / trip)

$\mathrm{uc}=$ time put empty container (hours / trip)

$\mathrm{dbc}=$ time between locations (hours / trip)

$\mathrm{T}_{\mathrm{HCS}}=$ time per trip

$\mathrm{h}=$ time to temporary shelter location

$\mathrm{s}=$ time to wait at the location

$\mathrm{P}_{\mathrm{HCS}}=$ pickup time

$\mathrm{N}_{\mathrm{d}} \quad=$ trip count (trip / day)

$\mathrm{H}=$ working time per day (hours)

$t_{1} \quad=$ from the pool to the first location

$t_{2} \quad=$ from last location to pool

$\mathrm{W}=$ factor off route (non-productive in all operational activities)

$$
\begin{aligned}
& \mathrm{P}_{\mathrm{SCS}}=\mathrm{Ct}(\mathrm{uc})+(\mathrm{np}-1)+(\mathrm{dbc}) \\
& \mathrm{T}_{\mathrm{SCS}}=\mathrm{P}_{\mathrm{SCS}}+\mathrm{h}+\mathrm{s} \\
& \mathrm{Nd}=\left[\mathrm{H}(1-\mathrm{W})-\left(t_{1}+t_{2}\right)\right] / \mathrm{T}_{\mathrm{HCS}}
\end{aligned}
$$

where:

$\mathrm{Ct}=$ number of containers that can be emptied per-trip (container / trip)

$\mathrm{uc}=$ time put empty container (hour / container)

$\mathrm{np}=$ number of containers emptied per-trip (location / trip)

$\mathrm{dbc}=$ time between locations (hour / location)

$\mathrm{T}_{\mathrm{SCS}}=$ time per-trip

$\mathrm{h} \quad=$ time to the temporary shelter location

$\mathrm{s} \quad=$ time to wait at the location

$\mathrm{P}_{\mathrm{SCS}}=$ pickup time

$\mathrm{N}_{\mathrm{d}}=$ trip count (trip / day)

$\mathrm{H} \quad=$ working time per day (hours)

$t_{1}=$ from the pool to the first location

$t_{2}=$ from last location to pool

$\mathrm{W}=$ factor off route (Non-productive in all operational activities)

The cost of transporting solid waste consists of moving costs and fixed costs. Moving costs include operating costs incurred by garbage trucks (fuel, engine oil, mechanics, tires, spare parts maintenance, depreciation, capital interest, vehicle insurance, driver and crew wages). Fixed costs is costs incurred when the vehicle is operating or not. Fixed costs are the fees stated in the local tax assessment letter.

The method used for moving costs calculation is the regression equation developed by PCI (Pacific Consultants International) (1990) .This method produces non-dimensional quantities and in units of $1000 \mathrm{~km}$, so to get the per-km unit value required distance data and average speed average of vehicle in operation and to get operating cost of vehicle with rupiah currency required monetary value regression equation of PCI model. 


\section{Results and Discussions}

\subsection{Trashloading Time and Amount Trip}

Armroll trucks serves eight temporary shelter locations in the Seberang Ulu area with $6 \mathrm{~m}^{3}$ container capacity and trip number (ritation) of one to 3 times a day. The furthest location to reach from the landfill is $18.9 \mathrm{~km}$, while the nearest location is $14 \mathrm{~km}$ away. Analysis of armroll trucks transport time by HCS method in one trip or ritation and the number of rit / day is calculated by equations (1), (2), and (3) which can be seen in table 3 .

Table 2. Trashloading Activities With Armroll Trucks (HCS Pattern).

\begin{tabular}{|c|c|c|c|c|}
\hline Number truck & 69 & 78 & 81 & 83 \\
\hline$t_{1}+t_{2}$ (hour) & 0.73 & 0.90 & 1.34 & 0.82 \\
\hline h (hour/rit) & 1.56 & 1.43 & 1.54 & 1.67 \\
\hline pc (hour/rit) & 0.26 & 0.24 & 0.29 & 0.29 \\
\hline uc (hour/rit) & 0.04 & 0.03 & 0.06 & 0.05 \\
\hline dbc (hour/rit) & 0.16 & 0.22 & 0.13 & 0.18 \\
\hline s (hour/rit) & 0.68 & 0.67 & 0.67 & 0.69 \\
\hline H (hour) & 9.00 & 9.00 & 9.00 & 9.00 \\
\hline W (hour/rit) & 0.08 & 0.33 & 0.40 & 0.18 \\
\hline V (km/hour) & 22.04 & 21.14 & 23.45 & 20.06 \\
\hline $\mathrm{P}_{\mathrm{HCS}}$ (hour/rit) & 0.46 & 0.49 & 0.48 & 0.52 \\
\hline $\mathrm{T}_{\text {HCS }}$ (hour/rit) & 2.70 & 2.59 & 2.69 & 2.88 \\
\hline $\begin{array}{c}\mathbf{T}_{\text {HCS }} \text { avarage } \\
\text { (hour/rit) }\end{array}$ & \multicolumn{4}{|c|}{2.72} \\
\hline $\mathrm{Nd}$ (rit/day) & 2.79 & 1.98 & 1.51 & 2.28 \\
\hline $\begin{array}{l}\text { Nd avarage } \\
\text { (rit/day) }\end{array}$ & \multicolumn{4}{|c|}{$2.14 \sim 3 \mathrm{rit} / \mathrm{day}$} \\
\hline
\end{tabular}

In the HCS pattern (Table 3), time haul of solid waste transportation observed directly in the field, consist of times from pool to temporary shelter $\left(t_{1}\right)$, time from landfil to pool $\left(\mathrm{t}_{2}\right)$, travel time from temporary shelter to landfill $\left(\mathrm{h}_{1}\right)$, travel time from landfill to temporary shelter $\left(\mathrm{h}_{2}\right)$, waiting time and raise the container $(\mathrm{pc})$, time to lower the container (uc), total time in landfil (s), operational time (t-operational) and average velocity (v), so that the required time of armroll truck in one trip is 2.72 hours / rit and the amount of trip is 3 rit / day. 
In the SCS pattern, the field observations of dump trucks at the time from pool to temporary shelter $\left(t_{1}\right)$, time from landfill to pool $\left(t_{2}\right)$, travel time from temporary shelter to landfill, and landfill to temporary shelter (h), time to empty the container (uc), time between temporary shelter sites (dbc), total time in landfill (s), number of containers emptied per rit (ct), number of container locations per rit (np), operating time (toperational), and average speed (v). Here is the analysis of solid waste transport system using dump trucks (table 4) using equations (4), (5), and (6).

Table 3. Trashloading activities with dump trucks (SCS pattern).

\begin{tabular}{|c|c|c|c|c|c|}
\hline Number truck & 85 & 86 & 87 & 88 & 100 \\
\hline $\mathrm{t}_{1}$ (hour) & 0.71 & 0.745 & 0.67 & 0.195 & 0.72 \\
\hline $\mathrm{t}_{2}$ (hour) & 0.02 & 0.03 & 0.74 & 1.07 & 0.49 \\
\hline h (hour/rit) & 0.55 & 1.59 & 1.56 & 1.54 & 1.45 \\
\hline uc (hour/container) & 0.29 & 2.39 & 0.19 & 0.24 & 0.69 \\
\hline dbc (hour/location) & 0.14 & 0.00 & 0.15 & 0.095 & 0.07 \\
\hline s (hour/rit) & 1.37 & 1.25 & 0.88 & 0.88 & 0.93 \\
\hline ct (container/rit) & 5.00 & 1.00 & 12.00 & 9.00 & 4.00 \\
\hline np (location/rit) & 3.00 & 1.00 & 5.00 & 5.00 & 4.00 \\
\hline t operational (hour) & 0.43 & 0.24 & 0.25 & 0.22 & 0.21 \\
\hline W (hour/rit) & 0.03 & 0.24 & 0.12 & 0.18 & 0.19 \\
\hline $\mathrm{V}(\mathrm{km} /$ hour$)$ & 26.01 & 22.18 & 20.69 & 23.01 & 22.8 \\
\hline PSCS (hour/rit) & 1.72 & 2.39 & 2.88 & 2.54 & 2.99 \\
\hline $\mathrm{T}_{\mathrm{SCS}}$ (hour/rit) & 4.63 & 5.23 & 5.32 & 4.95 & 5.37 \\
\hline $\begin{array}{c}\text { TSCS avarage }_{\text {(hour/rit) }} \\
\text { (hour }\end{array}$ & & & 4.77 & & \\
\hline $\begin{array}{l}\text { Nd avarage } \\
\text { (rit/day) }\end{array}$ & 1.73 & 1.16 & 1.22 & 5.37 & 1.13 \\
\hline $\begin{array}{c}\text { Nd avarage } \\
\text { (rit/day) }\end{array}$ & \multicolumn{5}{|c|}{$1.48 \sim 2 \mathrm{rit} / \mathrm{day}$} \\
\hline
\end{tabular}

There are 19 units of dump trucks serving the Seberang Ulu area and table 4 only shows 5 units of dump trucks from all units analyzed. The result of the analysis shows that the average time required in one rite is 4.77 hours / rit with the amount of ritation is 2 rit / day.

\subsection{Solid Waste Transporting Costs}

The calculation of the garbage haul cost (IDR / $\mathrm{m}^{3}$ ) of the armoll truck and dump truck using equations (7) to (16) is shown in Table 5 and Table 6. 
Garbage hauling costs by armroll trucks averaged IDR $13.433 / \mathrm{m}^{3}$ with average distance of $105.7 \mathrm{~km}$ from temporary shelter to landfill, and dump trucks of IDR 25,400.1 / $\mathrm{m}^{3}$ with average distance of $42.79 \mathrm{~km}$ from temporary shelter to landfil, or with other words, the cost of dump trucks transport is more expensive amount IDR $11,967.1 / \mathrm{m}^{3}$ with a shorter distance than armroll trucks. This is influenced by the different patterns of transport on both types of trucks where armroll trucks use HCS pattern that require less time and labor than SCS pattern employing manpower in loading and unloading of solid waste either in temporary shelter or in landfill.

Table 4. Calculation of armroll trucks cost

\begin{tabular}{|c|c|c|c|c|c|c|c|}
\hline $\begin{array}{l}\text { No } \\
\text { truck }\end{array}$ & $\begin{array}{c}\text { Container } \\
\text { capacity } \\
\left(\mathbf{m}^{3}\right)\end{array}$ & $\begin{array}{l}\text { Amount } \\
\text { ritation } \\
\text { (trip/day) }\end{array}$ & $\begin{array}{c}\text { Moving } \\
\text { costs / } \\
\text { day } \\
\text { (IDR) }\end{array}$ & $\begin{array}{c}\text { Fixed } \\
\text { costs / } \\
\text { day } \\
\text { (IDR) }\end{array}$ & $\begin{array}{c}\text { Garbage } \\
\text { haul costs } \\
\text { / day } \\
\text { (IDR) }\end{array}$ & $\begin{array}{c}\text { Garbage } \\
\text { haul costs } \\
\text { / day } \\
\left(\text { IDR/m } / \mathbf{m}^{3)}\right.\end{array}$ & $\begin{array}{c}\text { distance } \\
\text { to the } \\
\text { landfill } \\
(\mathbf{k m})\end{array}$ \\
\hline 69 & 6 & 3 & 236.375 .8 & 6.790 & 243.166 & 13.509 .2 & 102.7 \\
\hline 78 & 6 & 3 & 234.904 .0 & 6.790 & 241.694 & 13.427 .4 & 101.1 \\
\hline 81 & 6 & 3 & 265.859 .4 & 6.790 & 272.649 & 15.147 .2 & 117.1 \\
\hline 83 & 6 & 3 & 202.516 .1 & 7.200 & 209.716 & 11.650 .9 & 102.1 \\
\hline \multicolumn{5}{|c|}{ avarage } & 241.806 & 13.433 .7 & 105.7 \\
\hline
\end{tabular}

Table 5. Calculation of dump trucks cost

\begin{tabular}{|c|c|c|c|c|c|c|c|}
\hline $\begin{array}{c}\text { No } \\
\text { truck }\end{array}$ & $\begin{array}{c}\text { Container } \\
\text { capacity } \\
\mathbf{( ~ m}^{\mathbf{3}} \mathbf{)}\end{array}$ & $\begin{array}{c}\text { Amount } \\
\text { ritation } \\
\text { (trip/ } \\
\text { day) }\end{array}$ & $\begin{array}{c}\text { Moving } \\
\text { costs } / \\
\text { day } \\
\text { (IDR) }\end{array}$ & $\begin{array}{c}\text { Fixed } \\
\text { costs / } \\
\text { day } \\
\text { (IDR) }\end{array}$ & $\begin{array}{c}\text { Garbage } \\
\text { haul costs } \\
\text { / day } \\
\text { (IDR) }\end{array}$ & $\begin{array}{c}\text { Garbage } \\
\text { haul costs } \\
\text { / day } \\
\text { (IDR/m }\end{array}$ & $\begin{array}{c}\text { distance } \\
\text { to the } \\
\text { landfill } \\
\text { (km) }\end{array}$ \\
\hline 67 & 10 & 2 & 483.801 .3 & 7.636 & 491.437 & 24.571 .8 & 56.3 \\
\hline 68 & 6 & 2 & 216.757 .7 & 8.953 & 225.710 & 18.809 .2 & 31.8 \\
\hline 70 & 6 & 2 & 244.519 .9 & 8.953 & 253.473 & 21.122 .7 & 31.8 \\
\hline 71 & 6 & 2 & 438.429 .2 & 8.953 & 447.382 & 37.281 .8 & 61.35 \\
\hline 72 & 6 & 2 & 217.113 .9 & 7.200 & 224.314 & 18.692 .8 & 32.9 \\
\hline 73 & 6 & 2 & 244.899 .9 & 8.953 & 253.853 & 21.154 .4 & 39.3 \\
\hline 74 & 6 & 2 & 318.652 .8 & 8.907 & 327.560 & 27.296 .6 & 35.73 \\
\hline 75 & 6 & 2 & 226.298 .9 & 2.619 & 228.918 & 19.076 .5 & 35.9 \\
\hline 76 & 6 & 2 & 267.964 .9 & 2.619 & 270.584 & 22.548 .7 & 38.5 \\
\hline 77 & 6 & 2 & 302.636 .8 & 4.013 & 306.650 & 25.554 .1 & 43.9 \\
\hline 79 & 6 & 2 & 240.799 .0 & 7.200 & 247.999 & 20.666 .6 & 32.75 \\
\hline 80 & 6 & 2 & 237.926 .7 & 2.619 & 240.546 & 20.045 .5 & 35.05 \\
\hline 82 & 6 & 2 & 421.273 .2 & 7.200 & 428.473 & 35.706 .1 & 62.14 \\
\hline 84 & 6 & 2 & 320.078 .8 & 8.907 & 328.986 & 27.415 .5 & 39.49 \\
\hline 85 & 6 & 2 & 303.650 .0 & 8.907 & 312.557 & 26.046 .4 & 38.58 \\
\hline 86 & 6 & 2 & 234.232 .5 & 4.013 & 238.245 & 19.853 .8 & 37.48 \\
\hline
\end{tabular}




\begin{tabular}{|c|c|c|c|c|c|c|c|}
\hline 87 & 6 & 2 & 411.697 .6 & 2.619 & 414.317 & 34.526 .4 & 59.9 \\
\hline 88 & 6 & 2 & 385.493 .4 & 58.853 & 444.347 & 37.028 .9 & 50 \\
\hline 100 & 6 & 2 & 298.440 .8 & 4.013 & 302.454 & 25.204 .5 & 50.1 \\
\hline \multicolumn{5}{|c|}{ avarage } & 315.148 & $\mathbf{2 5 . 4 0 0 . 1}$ & $\mathbf{4 2 . 7 9}$ \\
\hline
\end{tabular}

\section{Conclusions}

In the HCS pattern using a truck armroll. obtained by result of analysis of 3 ritation / day with travel time 2.72 hour / ritation. while pattern of SCS using dump truck. obtained result of analysis 2 ritation / day and travel time 4.77 hour / ritation. This result is in accordance with the number of ritations that have been done at the research location. the length of time required by dump trucks at each ritual causes the transport to be ineffective and requires many truck units.

The cost requirement on the armroll operations of the truck is $13.433 .7 \mathrm{IDR} / \mathrm{m}^{3}$ with an average travel distance of $105.7 \mathrm{~km}$. and the need for dump truck operational costs is 25.401.1 IDR / $\mathrm{m}^{3}$ with an average travel distance of $42.79 \mathrm{~km}$. Dump trucks have greater operating costs than truck armrolls. which can be considered in planning future municipal solid waste transport systems. A disadvantage to the use of armroll trucks is the need for cornerstone and containers standard $\left(6 \mathrm{~m}^{3}\right)$ according to the size of the containers in the arm roll on the collection system. which sometimes can not be met due to limited land or solid waste volume that is not in accordance with the size of the container.

\section{References}

1. Christian Riuji Lohri. Ephraim Joseph Camenzind. Christian Zurbrugg. J. Waste Management 34 (2014)

2. P.A. Koushki. U. Al-Duaij. W. Al-Ghimlas. J. Waste Management 24 (2004)

3. Burhamtoro. Achmad Wicaksono. M. Bisri. Soemarno. J. American Journal of Engineering Research (AJER) 02 (2013)

4. Olukanni. D. O. Iroko. T. S.. Aremu. A. S. J. Pollution 1 (2015)

5. Manus Coffey. Adrian Coad. J. United Nations Human Settlements Programme (UNHABITAT 58 (2010)

6. Scott J. Callan. Janet M. Thomas. J. Land Economics. 77 (2001)

7. Amirhossein Malakahmad. Noor Diana Khalil. J. International Conference on Business. Engineering. and Industrial Applications (ICBEIA) (2011)

8. Bel. G.. Mur. M. J. Waste Management 29 (2009)

9. Agunwamba. J. C. Egbuniwe. N.. Ogwueleka. T. C. Journal of Solid Waste Technology and Management 29 (2003)

10. Standar Nasional Indonesia (SNI) 19-2454-2002. Tata cara teknik operasional pengelolaan sampah perkotaan (Badan Standarisasi Nasional (BSN). 2002) 